\title{
Analysis of genetic heterogeneity of Staphylococcus aureus strains isolated from food and clinical samples from northern Jordan using VNTR, toxin profiles and antibiograms
}

\author{
Ziad W Jaradat ${ }^{1 \star}$, Qutaiba O Ababneh ${ }^{1}$, Shahd Saraireh ${ }^{1}$, Thamer Abdullhalim ${ }^{1}$, Waseem Al Mousa ${ }^{1}$, Yaser \\ Tarazi $^{2}$, Tareq M Osaili ${ }^{3}$, Anas Al- Nabulsi ${ }^{3}$, and Ismail Saadoun ${ }^{4}$ \\ $1^{1}$ Department of Biotechnology and Genetic Engineering, Jordan University of Science and Technology, \\ P. O Box 3030 Irbid 22110 Jordan. \\ ${ }^{2}$ Department of Basic Veterinary Medicine, Jordan University of Science and Technology, \\ P. O Box 3030 Irbid 22110 Jordan. \\ ${ }^{3}$ Department of Nutrition and Food Technology, Jordan University of Science and Technology, \\ P. O Box 3030 Irbid 22110 Jordan. \\ ${ }^{4}$ Department of Applied Biology, College of Sciences, University of Sharjah, UAE. \\ Email: jaradatz@just.edu.jo
}

Received 3 August 2015; Received in revised form 15 April 2016; Accepted 14 June 2016

\begin{abstract}
Aims: Staphylococcus aureus is a Gram positive pathogen distributed worldwide and represents a rising problem for both hospitals and community. The aims of the study were to examine the antibiograms, toxin profiles as well as the genetic diversity of a set of $S$. aureus isolates from clinical and food samples.

Methodology and results: To get some insights on the genetic heterogeneity and test for the presence of certain virulence genes, all isolates were subjected to different PCR amplifications and antibiotic sensitivity analysis. The mecA gene was detected in both clinical and food isolates. Resistance to penicillin and amoxicillin was observed in both clinical and food isolates. About $88 \%$ of both food and clinical isolates harbored the toxin gene sea, while $70 \%$ and $29 \%$ of clinical and food isolates respectively, harbored sec. The seb gene was detected in $59 \%$ and $18 \%$ of clinical and food isolates, respectively. Dendrograms prepared from the VNTR, antibiograms and toxin profiles, revealed 89,52 and 12 clusters, respectively. Thus, suggesting a very high heterogeneity among the isolates.

Conclusion, significance and impact of study: Strains used in this study showed high heterogeneity when examined by VNTR or antibiograms, while appeared less heterogeneous when dendrogram was generated based on toxin profiles. This study highlights the fact that methicillin resistance in $S$. aureus might be generated within the health institutions or the community. Obtained results also might help health authorities understand the origin of methicillin resistant clones within the study area.
\end{abstract}

Keywords: Staphylococcus aureus, toxins, antibiotic resistance, Variable Number Tandem Repeat (VNTR)

\section{INTRODUCTION}

Staphylococcus is transient colonizer of skin and mucosal membranes of both humans and animals (Pantosti, 2012). Enterotoxin-producing $S$. aureus are recognized as the most frequent agents of the blood stream and skin infections (Vivoni and Moreira, 2005). Further, S. aureus is an important cause of pneumonia, postoperative wound infections as well as nosocomial infections (Lee, 2003). In addition, it is considered one of the most commonly food poisoning-associated pathogens. In fact, $S$. aureus is only second or third to Salmonella and Clostridium perfringens in causing food borne outbreaks worldwide (Atanassova et al., 2001; Alarcon et al., 2006). Symptoms like vomiting, diarrhea and abdominal pain usually appear within 2-6 $\mathrm{h}$ of ingesting the food that contain preformed toxin. Staphylococcus aureus is not an exclusive human pathogen (Alarcon et al., 2006). Nasal cavity and skin of birds and warm-blooded animals, especially pigs, are considered reservoirs for $S$. aureus (Leonard and Markey, 2008). In addition, S. aureus is the major pathogen causing mastitis in dairy cows leading to contaminating milk from affected cows (Katsuda et al., 2005). Indeed, Staphylococcus has been isolated from food animal carcasses such as pigs, sheep, goats, cows, camels and chickens (Leonard and Markey, 2008). In general, Staphylococcus reaches the 
food chain by unhygienic practices of food handlers and asymptomatic carriers. Therefore, the presence of this bacterium or its toxins in foods is usually indicative of lack of hygiene in the food production processes (Atanassova et al., 2001: Alarcon et al., 2006).

Bacterial pathogens frequently acquire resistance to commonly used antibiotics, making the control of their infections a problem. Staphylococcus aureus, particularly the Methicillin-resistant $S$. aureus (MRSA), is by far one of the most important bacterial pathogens responsible for nosocomial infections in health care settings with varying prevalence among different countries (Malachowa et al., 2005; Chmelnitsky et al., 2007). Studies conducted in Netherlands (Kadariya et al., 2014) reported about 20$42 \%$ of human MRSA cases belong to a livestock strain that was termed livestock-associated MRSA. The livestock-associated MRSA appears to have crossed the species barrier, resulting in zoonotic transmission (Köck et al., 2013). These findings highlight the fact that animals might be an important reservoir for MRSA infections. Further, besides being resistant to penicillin and methicillin, MRSA have been reported to develop multidrug resistance profiles (Pandya et al., 2014). The production of enterotoxins is another virulence factor that complicates the infections caused by these MRSA, as it is known that pathogenicity is related to a combination of toxin production, invasive capacity, and antibiotic resistance (Carfora et al., 2015).

Molecular typing plays an important role in epidemiological studies, particularly in tracing the passage of pathogens from the food chain to humans and vice versa. Such information is vital to evaluate the efficacy of an outbreak detection and prevention; and to help in studying evolutionary relationship of MRSA and other pathogens (Tenover et al., 2007). Further, understanding the relationship among pathogens from different sources is an important tool in understanding the mechanism of pathogen transfer between hospitals and community.

Multiple-Locus Variable Tandem Repeat (VNTR) analysis (MLVA) provide a good discriminatory power in molecular typing and classifying MRSA strain types and provide results comparable to those obtained by Pulse Field Gel Electrophoresis (PFGE) and other typing methods (Sabat et al., 2003, 2006; Ishino et al., 2007). The MLVA utilizes the fact that the numbers of repeat units at certain DNA loci varies among strains. This variation can be detected by PCR with specific primers that flank DNA loci containing the repeated sequences. This method can be used effectively to type methicillin resistant $S$. aureus and determine their diversity and genetic relatedness (Sabat et al., 2003). Antibiograms profile-based dendrogram analysis is another method to study the heterogeneity among the isolates. The method was successfully implemented to study the relatedness of different serotypes of Escherichia coli based on antibiograms profiles (Sumathi et al., 2008). In contrast, Kerouanton et al. (2007) used the method to study relatedness among a group of $S$. aureus using the antibiograms and reported that the method was not useful.

The aims of this study were to investigate and compare the frequency $S$. aureus toxin genes (sea, seb, sec, sed, see) as well as the antibiotic resistance profiles of strains isolated from food and clinical samples collected from the northern Jordan. The heterogeneity among the isolates was also investigated using the toxin profiles, antibiograms and was compared to the VNTR profiles.

\section{MATERIALS AND METHODS}

\section{Isolation of $S$. aureus from food samples}

A total of 360 raw meat samples (camels, beef, sheep, goats, chicken and fish), cow's and goat's milk were randomly collected and examined during a two years period, between 2007 and 2009 . Meat samples were obtained from abattoirs from 4 different governorates in Northern Jordan. Samples $(250 \mathrm{~g})$ were collected from different locations of each carcass. Chicken and fish samples were purchased from local supermarkets and were processed similar to meat samples. Milk samples were collected under aseptic conditions in sterile containers. Samples were inoculated onto Baird-Parker agar base (BPA) supplemented with egg yolk-tellurite emulsion (Oxoid UK) and incubated for $24 \mathrm{~h}$ at $37^{\circ} \mathrm{C}$. Typical $S$. aureus colonies were picked from each sample and tested for coagulase production using latex coagulase test kit (Plasmatec, Canada) as per manufacturer's instructions. Table 1 shows the samples used in the study and their sources.

\section{Staphylococcus aureus from clinical samples}

To study the heterogeneity and to understand the pattern of methicillin resistance among $S$. aureus in the northern city of Irbid, 50 clinical isolates of $S$. aureus were randomly selected from a pool of clinical samples. The clinical isolates were collected from different human samples (blood, urine, pus/wound, tissue, body fluids, ear and eye cultures, prosthetic infections, nasal swabs, sputum, and breast discharges) collected from patients referred to King Abdullah University Hospital or University of Jordan hospital laboratories at the same period the food samples were being collected. The identity of the patients from which the clinical isolates were collected were kept anonymous, and only the isolate's source of infection were presented; and thus an IRB approval was waved. Those isolates were identified biochemically using the Validity Index of Traditional Environmental Knowledge (VITEC) (Table 1). 
Table 1: Summary of the samples used in the study with their sources.

\begin{tabular}{|c|c|c|c|}
\hline $\begin{array}{l}\text { Sample } \\
\text { Group }\end{array}$ & Sample Source & $\begin{array}{l}\text { Number of } \\
\text { Samples }\end{array}$ & Details \\
\hline Food & $\begin{array}{l}\text { Chicken } \\
\text { Sheep's milk } \\
\text { Lamb } \\
\text { Fish } \\
\text { Cow's milk } \\
\text { Goat's meat } \\
\text { Camel's meat }\end{array}$ & $\begin{array}{l}6 \\
1 \\
1 \\
3 \\
21 \\
12 \\
10\end{array}$ & $\begin{array}{c}\text { F5, F7, F8, F9, F10, F11 } \\
\text { A29 } \\
\text { F22 } \\
\text { F61, F62, F63 } \\
\text { F64-F68, F70-F78, F80, F85, A23-A28 } \\
\text { A1-A12 } \\
\text { A13-A22 }\end{array}$ \\
\hline Clinical & Pus & 17 & $\begin{array}{c}\text { 1C, 3C, 4C, 12C, 27C, 34C, 35C, C53, C63, C79 } \\
\text { C81, C89, C163, C165, C169, C178, C179 }\end{array}$ \\
\hline & $\begin{array}{l}\text { Blood Culture and CVS } \\
\text { Wound Culture } \\
\text { Eye Culture } \\
\text { Ear Culture } \\
\text { Sputum } \\
\text { Urinary Catheter and Urinary } \\
\text { Tract infections }\end{array}$ & $\begin{array}{l}11 \\
3 \\
3 \\
1 \\
2 \\
7\end{array}$ & $\begin{array}{c}2 \mathrm{C}, 11 \mathrm{C}, 22 \mathrm{C}, 25 \mathrm{C}, 28 \mathrm{C}, 30 \mathrm{C}, \mathrm{C} 52, \mathrm{C} 71, \mathrm{C} 76, \mathrm{C} 77 \\
\mathrm{C} 171 \\
5 \mathrm{C}, 16 \mathrm{C}, 33 \mathrm{C} \\
6 \mathrm{C}, \mathrm{C} 32, \mathrm{C} 157 \\
31 \mathrm{C} \\
8 \mathrm{C}, \mathrm{C} 159 \\
10 \mathrm{C}, 17 \mathrm{C}, 21 \mathrm{C}, 24 \mathrm{C}, 29 \mathrm{C}, 32 \mathrm{C}, \mathrm{C} 127\end{array}$ \\
\hline Total & & 105 & \\
\hline
\end{tabular}

\section{Molecular confirmation of the presumptive S. aureus and mecA testing}

DNA from confirmed $S$. aureus colonies was extracted using Genomic Wizard DNA extraction kit (Promega, Wisconsin, USA) following the manufacturer's instructions. Coagulase positive isolates were then tested by PCR using primers specific for the thermonuclease gene, nuc, which is specific for $S$. aureus as described by Brakstad et al. (1992) (see Table 2). The isolates were then tested for the presence of methicillin resistance gene (mecA) following the method of Smyth et al. (2005) (Table 2).

\section{Multiple-Locus Variable-Number Tandem Repeat (VNTR) Analysis}

Staphylococcus aureus isolates were analyzed for MLVA using a set of 5 pairs of PCR primers described by Sabat et al. (2003) that simultaneously amplify the hyper variable VNTR regions of $s p a, s s p A$, clfA, clfB and $s d r$ genes (Table 2).

\section{Antibiotic resistance of the isolates}

The resistance profiles of the $105 \mathrm{~S}$. aureus isolates were determined using the disk diffusion method following the instructions of the Clinical and Laboratory Standards Institute (CLSI, 2007). All isolates were tested for resistance against the following 15 antibiotics; Cefoxitin (FOX), Vancomycin (VA), Chloramphenicol (C), Trimethoprim (SXT), Gentamycin (GN), Amikacin (AK), Teicoplanin (TEC), Tobramycin (TOB), Amoxicillin (AMC),
Penicillin (P), Tetracyclin (TE), Rifampicin (RA), Clindamycin (DA), Azithromycin (AZM), Erythromycin (E).

\section{Testing the isolates for the presence of enterotoxin genes}

All the isolates were tested for the presence of some enterotoxin genes sea, seb, sec, sed and see by PCR using the primers and amplification conditions described by Johnson et al. (1991) (Table 2). These genes were selected based on their importance. For instance, seb is a potential warfare agent while sec is implicated in endocarditis (Otto, 2014).

\section{Statistical analysis and phylogenetic tree development}

Results of the VNTR, the antibiograms and toxin profiles analysis were subjected to cluster analysis. Similarity analysis was performed from a combined binary matrix based on the absence (0) or presence (1) of an amplified DNA band or the resistance (1) or sensitivity (0) of the isolates to antibiotics using the Jaccard coefficient (Naffa et al., 2006). Strain clustering was performed by the unweighted pair group method with arithmetic mean (UPGMA) analysis. The statistical program SPSS, version 23 (IBM, USA) was used for the analysis. A 70\% similarity was arbitrarily used as a discriminating threshold to define homologous clusters. 
Table 2: Primers used in the study with their product size, sequence and their running conditions.

\begin{tabular}{|c|c|c|c|c|}
\hline $\begin{array}{l}\text { Primer } \\
\text { target }\end{array}$ & Primer sequence & Running conditions & $\begin{array}{l}\text { Product size } \\
\text { (bp) }\end{array}$ & References \\
\hline$m e c A$ & $\begin{array}{l}\text { F: 5'GCAATCGCTAAAGAACTAAG } \\
\text { R; 5'GGGACCAACATAACCTAATA }\end{array}$ & $\begin{array}{l}\text { Pre-denaturation } \\
94^{\circ} \mathrm{C} \text { for } 3 \text { min for the } \\
\text { first cycle; } 94^{\circ} \mathrm{C} \text { for } \\
10 \mathrm{sec} \text { (denaturation) } \\
\text { and } 53^{\circ} \mathrm{C} \text { for } 20 \mathrm{sec} \\
\text { (annealing) for the } \\
\text { next } 30 \text { cycles, and a } \\
\text { final extension step at } \\
72^{\circ} \mathrm{C} \text { for } 5 \text { min }\end{array}$ & 222 & $\begin{array}{l}\text { Smyth et al. } \\
(2001)\end{array}$ \\
\hline nuc & $\begin{array}{l}\text { F5' GCGATTGATGGTGATACGGTT } \\
\text { R5'AGCCAAGCCTTGACGAACTAAAGC }\end{array}$ & $\begin{array}{l}\text { Pre-denaturation at } \\
94^{\circ} \mathrm{C} \text { for } 1 \mathrm{~min} \text {, } \\
\text { annealing at } 55^{\circ} \mathrm{C} \text { for } \\
30 \mathrm{sec} \text { and extension } \\
\text { at } 72^{\circ} \mathrm{C} \text { for } 1.5 \text { min. } \\
\text { amplification was for } \\
37 \text { cycles }\end{array}$ & 270 & $\begin{array}{c}\text { Brakstad et al. } \\
\quad(1992)\end{array}$ \\
\hline clfA & $\begin{array}{l}\text { F 5'-GATTCTGACCCAGGTTCAGA } \\
\text { R5'-CTGTATCTGGTAATGGTTCTTT }\end{array}$ & $\begin{array}{l}\text { Pre-denaturation } \\
94^{\circ} \mathrm{C} \text { for } 5 \mathrm{~min} \text {, } \\
\text { followed by } 20 \text { cycles }\end{array}$ & Multiple & $\begin{array}{l}\text { Sabat et al. } \\
\quad(2003)\end{array}$ \\
\hline clfB & $\begin{array}{l}\text { F5'-ATGGTGATTCAGCAGTAAATCC } \\
\text { R5'-CATTATTTGGTGGTGTAACTCTT }\end{array}$ & $\begin{array}{l}\text { of } 30 \mathrm{sec} \text { at } 94^{\circ} \mathrm{C}, 30 \\
\mathrm{sec} \text { at } 55^{\circ} \mathrm{C}, 30 \mathrm{~s} \text { at } \\
72{ }^{\circ} \mathrm{C} \text { with final }\end{array}$ & & \\
\hline$s d r$ & $\begin{array}{l}\text { F5'-GTAACAATTACGGATCATGATG } \\
\text { R5'-TACCTGTTTCTGGTAATGCTTT }\end{array}$ & $\begin{array}{l}\text { extension at } 72{ }^{\circ} \mathrm{C} \text { for } \\
5 \mathrm{~min}\end{array}$ & & \\
\hline spa & $\begin{array}{l}\text { F5'-AGCACCAAAAGAGGAAGACAA } \\
\text { R5'-GTTTAACGACATGTACTCCGT }\end{array}$ & & & \\
\hline ד & $\begin{array}{l}\text { F5' -ATCMATTTYGCMAAYGATGACCA } \\
\text { R5'-TTGTCTGAATTATTGTTATCGCC }\end{array}$ & & & \\
\hline sea & $\begin{array}{l}\text { F; 5'- TTGGAAACGGTTAAAACGAA } \\
\text { R; 5'-GAACCTTCCCATCAAAAACA }\end{array}$ & $\begin{array}{l}\text { Pre-denaturation at } \\
94{ }^{\circ} \mathrm{C} \text { for } 2 \text { min } \\
\text { followed by annealing }\end{array}$ & 120 & $\begin{array}{l}\text { Johnson et al. } \\
\quad(1991)\end{array}$ \\
\hline seb & $\begin{array}{l}\text { F; 5'-TCGCATCAAACTGACAAACG } \\
\text { R;5'-GCAGGTACTCTATAAGTGCC }\end{array}$ & $\begin{array}{l}\text { for } 2 \text { min at } 55^{\circ} \mathrm{C} \text { and } \\
\text { extension for } 1 \mathrm{~min} \text { at } \\
72^{\circ} \mathrm{C} \text { and a final }\end{array}$ & 478 & \\
\hline $\sec$ & $\begin{array}{l}\text { F;5'-GACATAAAAGCTAGGAATTT } \\
\text { R;5'-AAATCGGATTAACATTATCC }\end{array}$ & $\begin{array}{l}\text { extension step at } 72 \\
{ }^{\circ} \mathrm{C} \text { for } 7 \text { min. total } 40 \\
\text { cycles }\end{array}$ & 257 & \\
\hline sed & $\begin{array}{l}\text { F;5'-CTAGTTTGGTAATATCTCCT } \\
\text { R;5'-TAATGCTATATCTTATAGGG }\end{array}$ & & 317 & \\
\hline see & $\begin{array}{l}\text { F;5'-TAGATAAAGTTAAAACAAGC } \\
\text { R;5'-TAACTTACCGTGGACCCTTC }\end{array}$ & & 170 & \\
\hline
\end{tabular}




\section{RESULTS AND DISCUSSION}

\section{Isolation and confirmation of the $S$. aureus isolates}

All isolates used in the study were characterized phenotypically by Gram stain, colony morphology on Bird Parker Agar (BPA) and for the presence of free plasma coagulase. All isolates used in this study were typical $S$. aureus strains as they appeared as dark grey to jet black colonies with opaque zones, surrounded by clear halo on BPA. Also, all isolates appeared as Gram-positive cocci under the microscope and tested positive for the coagulase test. To confirm the identity of the isolates, they were tested for the presence of thermonuclease gene (nuc), which is specific for $S$. aureus (Brakstad et al., 1992). As a result, 55 food and 50 clinical isolates were confirmed as $S$. aureus.

\section{Testing isolates for antibiotic resistance}

The antibiograms of all the isolates were depicted in Table 3. All the 50 tested clinical isolates were resistant to penicillin while 44 isolates were resistant to the amoxicillin, but none of the isolates were resistant to either vancomycin or teicoplanin. These results are comparable to the results reported by $\mathrm{Wu}$ et al. (2010), who also reported that $100 \%$ of the community acquired MRSA isolates were resistant to penicillin but not to vancomycin. Out of the 55 food isolates, 34 were resistant to penicillin and 32 to amoxicillin. Interestingly, there were 12 food isolates resistant to vancomycin and 23 isolates were resistant to rifampicin, which might indicate that these antibiotics are included in animal feed or used for animal disease treatment.

A multi-drug resistant isolate is defined as being resistant to three or more antibiotics. When the isolates were scrutinized for percentages of isolates exhibiting multi-drug resistance, $80 \%$ and $70 \%$ of the food and clinical isolates were multi-drug resistant, respectively. Among the food isolates, F63 was resistant to all the 15 tested antibiotics while one isolate (F70) was resistant to 10 antibiotics, and the rest showed resistance against 2 to 8 antibiotics. One food isolate was sensitive to all tested antibiotics. Two clinical isolates, C76 was resistant to 11 antibiotics, and $\mathrm{C} 127$ was resistant to 10 antibiotics while the other isolates showed resistance against 1 to 8 antibiotics. Nevertheless, the similar proportion of multidrug resistance among both clinical and food isolates observed in this study ( $80 \%$ vs $70 \%)$ contradicts the results obtained by Reinoso et al. (2008) who reported that resistance was pronounced among clinical $S$. aureus than those from food samples.

\section{Testing isolates for presence of mecA gene by PCR}

MRSA infections were reported in pet animals, in hospitalized patients and in community (Strommenger et al., 2006). However, it is not well known if the pet animals serve as reservoir for MRSA and transmit it to humans or vice versa (Pantosti, 2012).
Table 3: Antibiotic resistance profiles to clinical and food Staphylococcus isolates.

\begin{tabular}{lcccc}
\hline Antibiotic & $\begin{array}{c}\text { Clinical Isolates } \\
(50)\end{array}$ & \multicolumn{2}{c}{$\begin{array}{c}\text { Food Isolates } \\
(55)\end{array}$} \\
& $\mathrm{R}$ & $\mathrm{S}$ & $\mathrm{R}$ & $\mathrm{S}$ \\
\hline Vancomycin (VA) & 0 & 50 & 12 & 43 \\
Chloramphenicol & 3 & 47 & 1 & 54 \\
(C) & & & & \\
Trimethoprim & 9 & 41 & 19 & 36 \\
(SXT) & & & & \\
Gentamycin (GN) & 4 & 46 & 9 & 46 \\
Amikacin (AK) & 6 & 44 & 4 & 51 \\
Teicoplanin (TEC) & 8 & 42 & 14 & 41 \\
Tobramycin & 7 & 43 & 9 & 46 \\
(TOB) & & & & \\
Amoxicillin (AMC) & 44 & 6 & 32 & 23 \\
Penicillin (P) & 50 & 0 & 34 & 21 \\
Tetracyclin (TE) & 20 & 30 & 22 & 33 \\
Rifampicin (RA) & 4 & 46 & 23 & 32 \\
Clindamycin (DA) & 11 & 39 & 9 & 46 \\
Azithromycin & 18 & 32 & 16 & 39 \\
(AZM) & & & & \\
Erythromycin (E) & 21 & 29 & 10 & 45 \\
Cefoxitin (FOX) & 24 & 26 & 17 & 38 \\
\hline
\end{tabular}

When the isolates were tested for the presence of the mecA gene, 36 out of 50 clinical isolates $(72 \%)$ were positive, while 42 out of 55 food isolates (76\%) were positive. These numbers appeared to be very high in comparison to results of other studies (Tsen et al., 1998; de Boer et al., 2009). In fact, Tsen et al. (1998) reported a complete absence of MRSA in food isolates in Taiwan. The high number of isolates harboring the mecA gene and exhibiting multidrug resistance to most antibiotics used in this study suggests a major role for horizontal gene transfer. There is evidence that the mecA gene resides on a mobile genetic element that also harbor genes, which encode resistance to non-beta-lactam antibiotics, causing the observed multi-resistance (Wielders et al., 2002).

The presence of high percentage of MRSA in food isolates in Jordan might signify the widespread of this pathogen in the environment and consequently in the food animals and their products. In addition, it is well known that the presence of the mecA gene doesn't necessarily indicate a phenotypic methicillin resistance (Martineau et al., 2000). The difficulty in the detection of the MRSA phenotype stems from the heterogeneous expression of the mecA gene in strains of Staphylococcus, where each cell in a population may carry the genetic information but only 1 in $10^{5}-10^{7}$ cells may express the resistance phenotypically (Yamazumi et al., 2001).

Although resistance to cefoxitin was used as an indicator for methicillin resistance (Anand et al., 2009), in our study we did not observe any correlation between resistance to cefoxitin and presence of mecA gene. Only 24 out of 50 clinical isolates showed resistance to cefoxitin while 35 isolates harbored the mecA gene. 
Among the food isolates, only 17 out of 55 food isolates exhibited resistance to cefoxitin while 42 isolates harbored the mecA gene. In a study reported by Chauhan et al. (2013), all MRSA tested positive for cefoxitin. However, the authors did not test for the presence of the mecA gene by PCR and just depended on the phenotyping of the isolates by the traditional antimicrobial testing.

\section{Distribution of enterotoxin genes}

When the isolates were tested for the presence of the major enterotoxin genes (sea, seb, sec, sed, see), the distribution of these genes varied between the food and clinical isolates (Figure 1). The sea gene, which was the most abundant, was found in (88\%) of the clinical and food isolates, followed by sec (70 and $29 \%$ ) for clinical and food isolates, respectively. This result appeared in accordance with results reported by Kerouanton et al. (2007) who reported that sea was the most frequent in human isolates. In contrast, our results appeared contradicts results reported by Akineden et al. (2008) who stated that $\mathrm{sec}$ is mainly found in $S$. aureus isolated from food samples.

Nevertheless, these results were similar to reports by Mehrotra et al. (2000) and Becker et al. (2003). The high prevalence of toxin genes in strains isolated from food and clinical samples suggest that humans could have acquired the toxin harboring strains from contamination food products. As for the distribution of sea, similar results were reported by Omoe et al. (2002) who showed that $76 \%$ of isolates from food poisoning harbored the sea gene. The presence of seb genes was third with $56 \%$ and $18 \%$ of clinical and food isolates harbored the gene, respectively. The sed gene was only found in one clinical isolate (2\%), while see was found in $22 \%$ of the food isolates and only $4 \%$ of the clinical isolates. Although only one isolate harbored the sed toxin gene, Morandi et al. (2009) reported that sed gene was the most frequent gene at $30 \%$ of $S$. aureus from dairy products harboring that gene. This indicates that high variation among the isolates is based on location and origin of samples.

When evaluating the distribution of toxin genes among the isolates, almost all isolates $(103 / 105,98 \%)$ harbored at least one type of toxin genes, except two isolates originated from food samples (A27 and F22) were devoid of any toxin gene. Our result appeared in agreement with results reported by two studies (Ferry et al., 2005; Morandi et al., 2009). Ferry et al. (2005) reported that $84 \%$ of the $S$. aureus clinical isolates harbored at least one toxin gene and Morandi et al. (2009) reported that $79 \%$ of $S$. aureus from dairy products harbored at least one toxin gene. In contrast, Peles et al. (2007) reported that only $15 \%$ of $S$. aureus isolated from milk samples in Hungary harbored at least one toxin gene. This could be due to the homogeneity of the $S$. aureus isolates used in their study. The sea gene was detected in the majority of isolates from clinical (44 out of 50) and food (49 out of 55) samples. Similar results were reported by Akineden et al. (2008) who found that most of tested clinical samples harbored the sea gene.

When the isolates were analyzed for the number of toxin genes they harbored, 40 isolates contained one toxin gene while, 34 isolates contained two toxin genes, 26 isolates contained 3 toxin genes and only 3 clinical isolates contained 4 toxin genes. Collectively, our results and results reported by others suggest that toxin gene profiles vary from place to place and there is no rule to whether food or clinical isolates harbor a certain type of toxin genes.

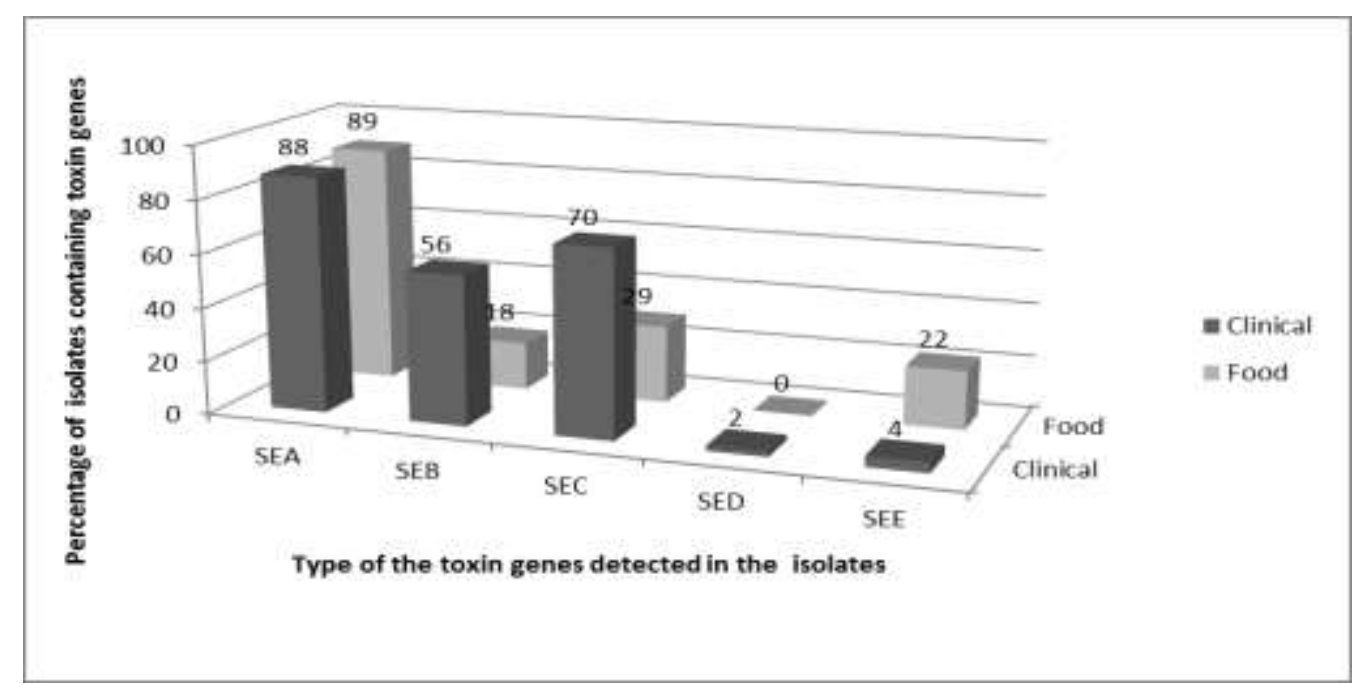

Figure 1: Distribution of enterotoxin genes as detected by PCR among food and clinical $S$. aureus isolates. 


\section{Phylogenetic analysis of the isolates using VNTR, antibiograms and toxin profiles}

In this study, we used VNTR analysis to study the genetic heterogeneity among our collection of food and clinical isolates. PCR amplification of extracted DNA gave multiple bands (4-8 bands) with a size ranging from $90 \mathrm{bp}$ to $2156 \mathrm{bp}$ for all the isolates. Genomic heterogeneity among the isolate is considerable and is reflected in the high number of banding patterns, as the 105 isolates generated 92 patterns or subtypes when a dendrogram was constructed from the VNTR analysis data. When a $70 \%$ similarity cut-off was arbitrarily set for the dendrogram analysis, the isolates were clustered in 89 clusters indicating a very high heterogeneity, which deem the method non-discriminatory among the isolates. These results contradict the results published by Morandi et al. (2010) who reported that this method was capable of differentiating between food and clinical isolates. Tenover et al. (2007) also used the same method to type 103 clinical and community associated MRSA and was able to identify 13 clusters with PFGE typing from 42 banding patterns using $75 \%$ similarity cut off. In the same study, when the same isolates were typed by VNTR, 9 clusters were identified with 36 unique VNTR patterns (Tenover et al., 2007). These differences between our results and the results reported by Tenover et al. (2007) and Morandi et al. (2010) highlight the high heterogeneity of the isolates examined in this work.

As an alternative to the VNTR analysis, the antibiograms for the isolates were used to generate a dendrogram. A $70 \%$ similarity cut-off was also used to identify the clusters. The antibiograms generated 52 clusters with 33 single-isolate clusters while the other 19 clusters contain multiple isolates (Table 4). Some of these isolates contained only clinical isolates while others contain only food isolates and the rest contained mixed isolates. Observing the patterns of the antibiograms for each cluster shows major differences between clusters (e.g clusters 12, 25 and 30 ) while there is similarity in the antibiograms within some clusters (e.g cluster 5, 42 and 47) indicating the limited usefulness of this method to study the antibiograms patterns of a collection of isolates. This finding is in agreement with Kerouanton et al. (2007) who arrived at the same conclusion. Nevertheless, the toxin profiles were used to generate a dendrogram using a $70 \%$ similarity cut-off (Figure 2). The toxin profiles generated only 12 clusters with 3 clusters (3, 5 and 8 ) contains 32,17 and 23 isolates, respectively (Table 5). The rest of the isolates were distrusted among the other 9 clusters with two clusters each contain one isolate. Noticeably, the toxin profiles in each cluster were identical for all the isolates in that cluster irrespective of the isolate origin. This method exhibits a good discriminatory power as opposed to the VNTR and the antibiograms profiles. These results are consistent with the concept of host specialization where some animal isolates were grouped in clusters while clinical isolates were grouped in other clusters (Reinoso et al., 2004). In addition some clusters contained isolates from food and clinical origin with the same toxin gene profiles indicating some genetic relatedness.

Table 4: The clusters of the tested bacteria based on antibiograms profiles.

\begin{tabular}{|c|c|c|c|}
\hline $\begin{array}{l}\text { Cluster } \\
\text { Number }\end{array}$ & Isolates & Antibiotic resistance profile at $70 \%$ similarity & Remarks \\
\hline 1 & $\mathrm{~A} 21, \mathrm{~A} 29,22 \mathrm{C}$ & $\begin{array}{l}\text { A21, A29; P, TOB, TEC } \\
\text { 22C; E, P, TOB, TEC }\end{array}$ & Mixed isolates \\
\hline 2 & C63, F11 & $\begin{array}{l}\text { C63: TE, P, AMC, TEC, OX } \\
\text { F11: TE, P, AMC, TEC }\end{array}$ & Mixed isolates \\
\hline 3 & $\mathrm{~A} 13, \mathrm{~A} 25, \mathrm{~A} 1$ & $\begin{array}{l}\text { A13; TE, P, AMC, TEC, VA } \\
\text { A25: E, TE, P, AMC, VA } \\
\text { A1: P, AMC, TEC, VA }\end{array}$ & $\begin{array}{l}\text { All are food/animal } \\
\text { isolates }\end{array}$ \\
\hline 4 & $10 \mathrm{C}, 32 \mathrm{C}$ & $\begin{array}{l}10 \mathrm{C} ; \mathrm{P}, \mathrm{AMC}, \mathrm{TOB} \\
32 \mathrm{C} ; \mathrm{TE}, \mathrm{P}, \mathrm{AMC}, \mathrm{TOB}\end{array}$ & $\begin{array}{l}\text { Both are clinical } \\
\text { isolates }\end{array}$ \\
\hline 5 & $\begin{array}{l}\text { A11, A23, A2, 2C, } \\
34 C, 27 C, 29 C, 21 C, \\
25 C, 11 C, 17 C, 8 C, \\
12 C, 5 C\end{array}$ & $P^{*}, A M C$ & $\begin{array}{l}\text { Majority are clinical } \\
\text { with only } 3 \text { food } \\
\text { isolates with identical } \\
\text { antibiograms }\end{array}$ \\
\hline 9 & $\mathrm{~A} 10, \mathrm{~A} 12$ & $\begin{array}{l}\text { A10; FOX, TE, P, AMC, SXT, MET } \\
\text { A12; FOX, TE, P, AMC, SXT }\end{array}$ & Both are food isolates \\
\hline 11 & A9, A19, A5 & $\mathrm{P}, \mathrm{AMC}, \mathrm{SXT}$ & $\begin{array}{l}\text { All are food isolates } \\
\text { with identical } \\
\text { antibiograms }\end{array}$ \\
\hline 12 & A22, A27, A8, A15 & $\begin{array}{l}\text { A22, A27, A8; TE, P, AMC, SXT } \\
\text { A15; TE, P, AMC, TEC, SXT }\end{array}$ & All are food isolates \\
\hline 14 & C79, F9 & $\begin{array}{l}\text { C79; E, TE, P, AMC } \\
\text { F9; E, TE, P, AMC }\end{array}$ & Mixed \\
\hline 16 & A20, A26 & $\begin{array}{l}\text { A20; E, DA, TE, P, AMC, SXT } \\
\text { A26; E, DA, TE, P, AMC, TEC, SXT, VA }\end{array}$ & Both food isolates \\
\hline
\end{tabular}


Mixed source but

C169, C171, C163, C165, C167

FOX, P, AMC, TEC, SXT

C76; E, AZM, DA, FOX, TE, P, AMC, TOB, AK, GEN, SXT

C127; E, AZM, FOX, TE, P, AMC, TOB, AK, GEN, SXT

C53; E, AZM, RA, FOX, TE, P, AMC, TOB, AK, GEN, SXT

F63**; E, AZM, DA, RA, FOX, TE, P, AMC, TOB, TEC, AK, GEN, SXT, C, VA

C159, C178, C74 C159, C178, C74, C89; E, AZM, FOX, TE, P, C89, C177, C157, AMC C158, C174

C177; E, AZM, FOX, TE, P, AMC, TEC C157; E, AZM, FOX, TE, $P$ C158; E, AZM, FOX, TE, P, AMC C174; E, AZM, DA, FOX, TE, P, AMC, SXT

11C, F5; E, AMZ, DA, RA, FOX, P, AMC F8; E, AMZ, DA, RA, FOX, TE, P, AMC 24C; E, AMZ, DA, RA, FOX, P, AMC, AK AMZ, RA, FOX, TOB, TEC, GEN

F61; AMZ, RA, TOB, GEN F77; AMZ, RA, TOB

AMZ, RA

Mixed source, and different antibiograms Both are clinical with identical antibiograms All are clinical with identical antibiograms

All are clinical but with different antibiograms

Mixed source and different antibiograms

All are food isolates with identical antibiograms

Both are food isolates All are food isolates with similar antibiograms

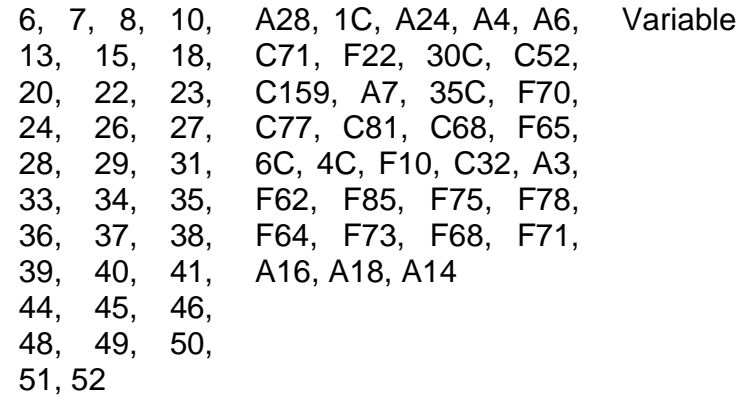

All of these are clusters with single isolate in each with different antibiograms 


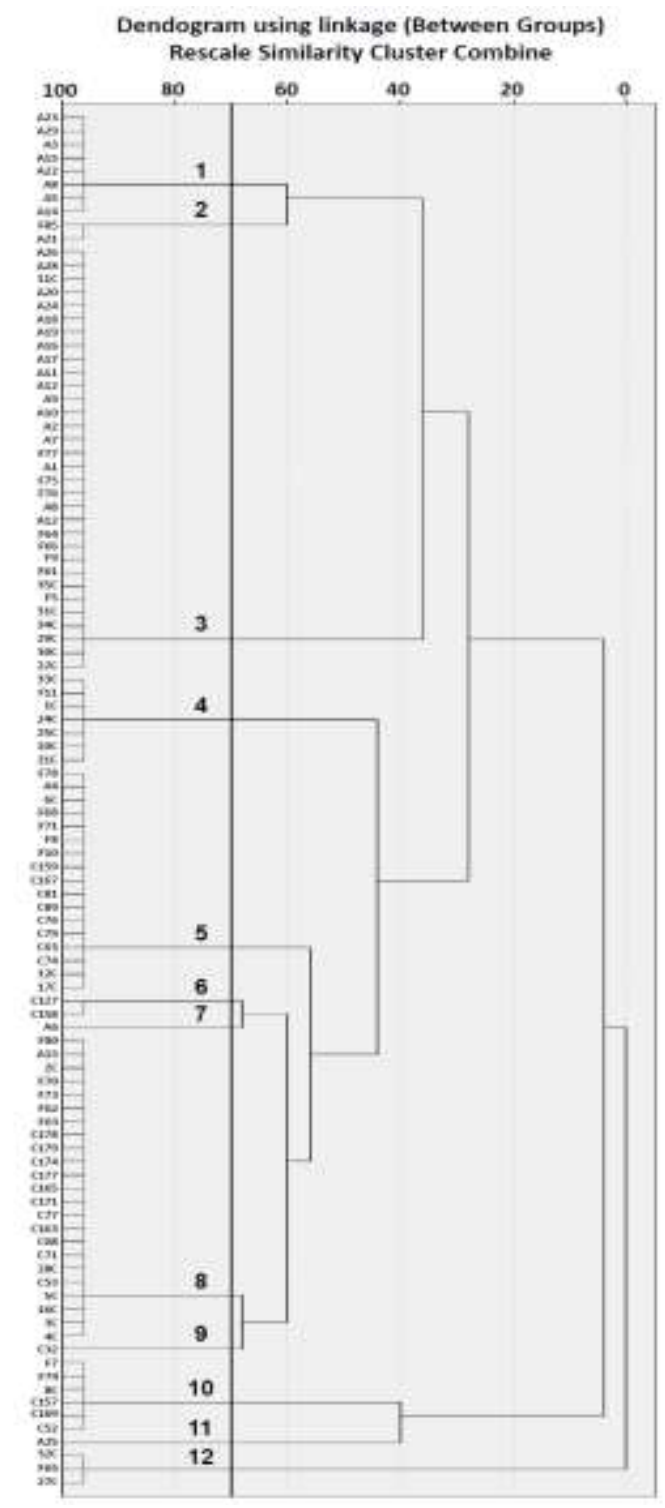

Figure 2: Dendrogram generated using unweighted pair group method with arithmetic average analysis using toxin gene patterns. Similarity analysis was performed from combined binary matrix based on the presence of a toxin (1) or the absence of the toxin (0) using the Jaccard coefficient performed by unweighted pair group method with arithmetic mean (UPGMA) analysis. The cut-off was arbitrarily set at $70 \%$ similarity level and classified the isolates into 12 different clusters 1-12. The scale at the top show the similarity index as a discriminating threshold to define homogenous clusters.

\section{CONCLUSIONS}

In conclusion, it appears that when using $70 \%$ similarity, the VNTR as well as the antibiograms profiles did not provide enough discriminatory power to cluster the isolates based on the origin, and thus very high cluster numbers were obtained, which indicates a very high heterogeneity among the isolates. In contrast, profiling the isolates based on the presence of toxin genes provided a far better discriminatory power to cluster the isolates based on their origin. The high heterogeneity of the isolates and the apparent clustering of either food or clinical in separate clusters revealed that the origin of the $S$. aureus isolates in clinical and food are different. Nevertheless, the toxin patterns of some food and clinical isolates were identical indicating a very close relationship among those. Further, it is a possibility that some human infections were caused by consuming contaminated food products made from these animals.

\section{ACKNOWLEDGEMENTS}

The authors would like to thank the Department of Biotechnology and Genetic Engineering at the Jordan University of Science and Technology for allowing this research to be completed at its premises and for financial assistance. The authors would like also to extend their gratitude to Ms Hanadi Ennab for her technical assistance.

\section{REFERENCES}

Anand, K. B., Agrawal, P., Kumar, S. and Kapila, K. (2009). Comparison of cefoxitin disc diffusion test, oxacillin screen agar, and PCR for mecA gene for detection of MRSA. Indian Journal of Medical Microbiology 27, 27-29.

Akineden, O., Hassan, A. H., Schneider, E. and Usleber, E. (2008). Enterotoxigenic properties of Staphylococcus aureus isolated from goats milk cheese. International Journal of Food Microbiology 124, 211-216.

Alarcon, B., Vicedo, B. and Aznar, R. (2006). PCRbased procedures for detection and quantification of Staphylococcus aureus and their application in food. Journal of Applied Microbiology 100, 352-364.

Atanassova, V., Meindl, A. and Ring, C. (2001). Prevalence of Staphylococcus aureus and staphylococcal enterotoxins in raw pork and uncooked smoked ham- a comparison of classical culturing detection and RFLP-PCR. International Journal of Food Microbiology 68, 105-113.

Becker, K., Friedrich, A., Lubritz, G., Weilert, M., Peters G. and von Eiff, C. (2003). Prevalence of genes encoding pyrogenic toxin superantigens and exofoliative toxins among strains of Staphylococcus aureus isolated from blood and nasal specimens. Journal of Clinical Microbiology 41, 1434-1439.

Brakstad, O. G., Aback, K. and Mealand, J. A. (1992). Detection of Staphylococcus aureus by polymerase chain reaction amplification of the nuc gene. Journal of Clinical Microbiology 30, 1654-1660.

Carfora, V., Caprioli, A., Marri, M., Sagrafoli, D., Boselli, C., Giacinti, G., Giangolini, G., Sorbara, L., Dottarelli, S., Battisti, A. and Amatiste, S. (2015). Enterotoxin genes, enterotoxin production, and 
methicillin resistance in Staphylococcus aureus isolated from milk and dairy products in central Italy. International Dairy Journal 42, 12-15.

Chauhan, P., Bais P. S. and Gupta N. (2013). Prevalence of methicillin resistant Staphylococcus aureus (mecA gene) among patients admitted in intensive care unit. International Journal of Bioassays 2, 1256-1259.

Chmelnitsky, I., Navon-Venezia, S., Leavit, A., Somekh, E., Regev-Yochai, G., Chowers, M., Shitrit, P. and Carmeli Y. (2007). SCCmec and spa types of methicillin-resistant Staphylococcus aureus strains in Israel. Detection of SCCmec type V. European Journal of Clinical Microbiology Infectious Diseases 27, 385-390.

Clinical and Laboratory Standards Institute (CLSI) (2007). Performance standards for antimicrobial susceptibility testing; $175^{\text {th }}$ informational supplement. CLSI document M100-S17, Vol 27.

de Boer, E., Zwartkruis-Nahuis, J. T. M., Wit, B., Huijsdens, X. W., de Neeling, A. J., Bosch, T., van Oosterom, R.,A.,A., Vila, A. and Heuvelink A. E. (2009). Prevalence of methicillin-resistant Staphylococcus aureus in meat. International Journal of Food Microbiology 134, 52-56.

Ferry, T., Thomas, D., Genestier, A-L., Bes, M., Lina, G., Vandenesch, F. and Etinne J. (2005). Comparative prevalence of superantigen genes in Staphylococcus aureus isolates causing sepsis with and without septic shock. Clinical Infectious Diseases 41, 771-777.

Ishino, K., Tsuchizaki, N., Ishikawa, J. and Kusefulness, H. (2007). Usefulness of PCRrestriction fragment length polymorphism typing of the coagulase gene to discriminate arbekacinresistant methicillin-resistant Staphylococcus aureus strains. Journal of Clinical Microbiology 45, 607-609.

Johnson, W. M., Taylor, S. D., Ewan, E. P., Ashton, F. E., Pollard, D. R. and Rozee, K. R. (1991). Detection of genes for enterotoxins, exfoliative toxins and toxic shock syndrome toxin 1 in Staphylococcus aureus by the polymerase chain reactions. Journal of Clinical Microbiology 29, 426-430.

Kadariya, J., Smith, T. C. and Thapaliya D. (2014). Staphylococcus aureus and Staphylococcal disease: An ongoing challenge in public health. Biomed Research International 2014 ID827965.

Katsuda, K., Hata, E., Kobayashi, H., Kohmoto, M., Kawashima, K., Tsunemitsu, H. and Eguchi, M. (2005). Molecular typing of Staphylococcus aureus from bovine mastitic milk on the basis of toxin genes and coagulase gene polymorphisms. Veterinary Microbiology 105, 301-305.

Kerouanton, A., Hennekinne, J. A., Letertre, C., Petit, L., Chesneau, O., Brisabois, A. and De Buyser, M. L. (2007). Characterization of Staphylococcus aureus strains associated with food poisoning outbreaks in France. International Journal of Food Microbiology 115, 369-375.
Köck, R., Schaumburg, F., Mellmann, A., Köksal, M., Jurke, A., Becker, K. and Friedrich, A. W. (2013). Livestock-associated methicillin-resistant Staphylococcus aureus (MRSA) as causes of human infection and colonization in Germany. PLOS One 8, e55040.

Lee, J. H. (2003). Methicillin (Oxacillin)-resistant Staphylococcus aureus strains isolated from major food animals and their potential transmission to humans. Applied and Environmental Microbiology 69, 6489-6494.

Leonard, F.C. and Markey B. K. (2008). Methcillinresistant Staphylococcus aureus in animals: A review. The Veterinary Journal 175, 27-36.

Malachowa, N., Saabat, A., Gniadkowski, M., Krzyszton-Russjan, J., Empel, J., Miedzobrodzki, J., Kosowska-shick, K., Appelbaum, P. C. and Hryniewicz, W. (2005). Comparison of multiplelocus variable-number tandem-repeat analysis with pulsed-field gel electrophoresis, spa typing, and multilocus sequence typing for clonal characterization of $S$. aureus isolates. Journal of Clinical Microbiology 43, 3095-3100.

Martineau, F., Picard, F. J., Lansac, N., Menard, C., Roy, P. H., Ouellette, M. and Bergeron, M. G. (2000). Correlation between the resistance genotype determined by multiplex PCR assays and the antibiotic susceptibility patterns of Staphylococcus aureus and S. epidermidis. Antimicrobial Agents and Chemotherapy 44, 231-238.

Mehrotra, M., Wang, G. and Johnson W. M. (2000). Multiplex PCR for detection of genes for Staphylococcus aureus enterotoxins, exfoliative toxins, toxic shock syndrome toxin 1 , and methicillin resistance. Journal of Clinical Microbiology 38, 10321035.

Morandi, S., Brasca, M., Andrighetto, C., Lombardi, A. and Lodi, R. (2009). Phenotypic and genotypic characterization of Staphylococcus aureus strains from Italian dairy products. International Journal of Microbiology Article ID 501362. DOI:10.1155/2009/ 501362.

Morandi, S., Brasca, M., Lodi, R., Brusetti, L., Andrighetto, C. and Lombardi, A. (2010). Biochemical profiles, restriction fragment length polymorphism (RFLP), random amplified polymorphic DNA (RAPD) and multilocus variable number tandem repeat analysis (MLVA) for typing Staphylococcus aureus isolated from dairy products. Research in Veterinary Science 88, 427-435.

Naffa, R. G., Bdour, S. M., Migdadi, H. M. and Shehabi, A. A. (2006). Enterotoxicity and genetic variation among clinical Staphylococcus aureus isolates in Jordan. Journal of Clinical Microbiology 55, 183-187.

Omoe, K., Ishikawa, M., Shimoda, Y., Hu, D-L., Ueda, S. and Shinagawa, K. (2002). Detection of seg, she, and sei genes in Staphylococcus aureus isolates and determination of the enterotoxin productivities of $S$. 
aureus isolates harboring seg, she or sei genes. Journal of Clinical Microbiology 40, 857-862.

Pandya, N., Chaudhary, A., Mehta, S. and Parmar, R. (2014). Characterization of Methicillin Resistant Staphylococcus aureus from various clinical samples at tertiary care hospital of rural Gujarat. Journal of Research in Medical and Dental Science 2, 49-53.

Pantosti, A. (2012). Methicillin-resistant Staphylococcus aureus associated with animals and its relevance to human health. Frontiers in Microbiology 3, 127.

Peles, F., Wagner, M., Varga, L., Hein, I., Rieck, P., Gutser, K., Kereszture, P., Kardos, G., Turcsanyi, I., Beri, B. and Szabio, A. (2007). Characterization of Staphylococcus aureus strains isolated from bovine milk in Hungary. International Journal of Food Microbiology 118, 186-193.

Reinoso, E. B., El -Sayed, A., Lämmler, C., Bogni, C. and Zschöck, M. (2008). Genotyping of Staphylococcus aureus isolated from humans, bovine subclinical mastitis and food samples in Argentina. Microbiological Research 163, 314-322.

Reinoso, E., Bettera, S., Frigerio, C., Direnzo, M., Calzolari, A. and Bogni, C. (2004). RAPD-PCR analysis of Staphylococcus aureus strains isolated from bovine and human hosts. Microbiological Research 159, 245-255.

Sabat, A., Krzyszton-Russjan, J., Strzalka, W., Filipek, R., Kosowska, K., Hryniewicz, W., Travis, J. and Potempa, J. (2003). New method for typing Staphylococcus aureus strains; Multiple-Locus Variable-Number Tandem Repeat Analysis of polymorphism and genetic relationships of clinical isolates. Journal of Clinical Microbiology 41, 18011804.

Sabat, A., Malachowa, N., Miedzobrodzki, J. and Hryniewicz, W. (2006). Comparison of PCR-based methods for typing $S$. aureus isolates. Journal of Clinical Microbiology 44, 3804-3807.

Smyth, R. W., Kahlmeter, G., Olsson Liljequist, B. and Hoffman, B. (2001). Methods for identifying methicillin resistance in Staphylococcus aureus. Journal of Hospital Infections 48, 103-107.

Strommenger, B., Kehrenberg, C., Kettlitz, C., Cunny, C., Verspohl, J., Witte, W. and Schwarz, S. (2006). Molecular characterization of methecillin-resistant Staphylococcus aureus strains from pet animals and their relationship to human isolates. Journal of Antimicrobial Chemotherapy 57, 461-465.

Sumathi, B. R., Amitha, R. G. and Krishnappa, G. (2008). Antibiogram profile based dendrogram analysis of Escherichia coli serotypes isolated from bovine mastitis. Veterinary World 1, 37-39.

Tenover, F. C., Vaughn, R. R., McDougal, L. K., Fosheim, G. E. and McGowan, J. E. (2007). Multiple-Locus Variable-Number Tandem-Repeat Assay Analysis of Methicillin-Resistant Staphylococcus aureus Strains. Journal of Clinical Microbiology. 45, 2215-2219.

Tsen, H. Y., Yu, G. K., Wang, K. C., Wang, S. J., Chang, M. Y. and Lin, L. Y. (1998). Comparison of the enterotoxigenic types, toxic shock syndrome toxin (TSST-1) strains and antibiotic susceptibility for enterotoxigenic Staphylococcus aureus strains isolated from food and clinical samples. Food Microbiology 15, 33-41.

Vivoni, A. M. and Moreira, B. M. (2005). Application of molecular techniques in the study of Staphylococcus aureus clonal evolution- a review. Memórias do Instituto Oswaldo Cruz 100, 693-698.

Wielders, C. L. C., Fluit, A. C., Brisse, S., Verhoef, J. and Schmitz, F. J. (2002). mecA gene is widely disseminated in Staphylococcus aureus population. Journal of Clinical Microbiology 40, 3970-3975.

Wu, D., Wang, Q., Yang, Y., Geng, W., Wang, Q., Yu, S., Yao, K., Yaun, L. and Shen X. (2010). Epidemiology and molecular characteristics of communityassociated methicillin-resistant and methicillinsusceptible Staphylococcus aureus from skin/soft tissue infections in a children's hospital in Beijing, China. Diagnostic Microbiology and Infectious Diseases 67, 1-8.

Yamazumi, T., Furuta, I., Diekema, D. J., Pfaller, M. A. and Jones, R. N. (2001). Comparison of the Vitek Gram-positive susceptibility 106 card, the MRSAscreen latex agglutination test, and mecA analysis for detecting oxacillin resistance in a geographically diverse collection of clinical isolates of coagulasenegative staphylocci. Journal of Clinical Microbiology 39, 3633-3636. 